\title{
ARTICLE 53 OF THE VIENNA CONVENTION ON THE LAW OF TREATIES - CODIFICATION OR DEVELOPMENT?
}

\author{
Jerzy Menkes*
}

\section{Background of non-legal character}

Many lawyers, in the course of their ius cogens studies, surpass dogmatic-legal analysis and, while assessing a legal norm through its relation with moral $^{1}$ norms, formulate apologetic opinions ${ }^{2}$ The authors of d'Amato's ${ }^{3}$ international law anthology univocally award Article 53 of the Vienna Convention on the Law of Treaties (VCLT), which falls within the category of ius cogens norms in international law, with an Oscar for

* Professor, Law Faculty, Warsaw School of Social Sciences and Humanities.

1 They make a separate normative system of international relations, for more see: J. Gilas, Norma prawa międzynarodowego [Norm of International Law] [in:] 'Polska i Świat' [Poland and the World], Poznań 1978, p. 129 ff.

2 Frankowska stresses ius cogens affinity with legal, not moral norms catalogue. M. Frankowska, Prawo traktatów [Law of the Treaties], Warszawa 1997, p. 145. However, Visscher consideres ius cogens as a notion of ethics; see P. de Visscher, Cours général de droit international public, 'Recueil de Cours de l'Académie de Droit International' 1972 (II), Vol. 136, p. 108.

3 A. d'Amato, International Law Anthology, Boston 1994, pp. 115-121. 
"the best legal norm", thus recognizing it as "Just Right". In this way, they pursue non-legal reflection during a debate on the legal components of international reality. This unanimous opinion on VCLT Article 53 proves a dramatic change when compared with divergent opinions held on the norm of Article 53 at the Commission of International Law and at the Vienna Conference. Voting evidenced the discrepancies: 8 states opposed the inclusion of Article 53 (Austria, Belgium, France ${ }^{4}$, Lichtenstein, Luxemburg, Monaco, Switzerland and Turkey), whilst a further 12 states abstained (Ireland, Japan, Malta, Norway, New Zealand and Great Britain). Yet negative and abstaining votes did not constitute a refusal to assign a peremptory status to certain international law norms, and therefore to the ultimate structuring of international law in a hierarchical manner. Analysis of states' legal argumentation before the International Law Commission and during the Conference proves that, while proponents argued for establishment of the institution, opponents rejected a method adopted to those ends, the law-making technique, and questioned its fundamental flaws.

D'Amato's text indicates yet another aspect of the introduction of ius cogens norms into the international law system, aside from the articulation of certain values. He considers ius cogens to be the Superman amongst norms $s^{5}$. This comparison reflects a conviction that in response to malice and the impotence of law (arguably also amongst institutions), a group of international law norms, constituting also "old" norms since none of the ius cogens norms were new, has been transformed in order to create a superpower to combat evil, to change the world. In order to significantly re-balance powers in the struggle of good against evil, a new status was simply bestowed upon legal norms (the normative hierarchical structuring of international law). To attain that goal, neither the establishment of new institutions nor the evolution of old ones was necessary.

A statement made by India's representative before the International Law Commission constitutes indirect evidence of the expectations to which the Anthology refers. Pal considered ius cogens as an element of the

4 France was so persistently objected ius cogens norms, that as the only state voted against VCLT.

A. d'Amato, op. cit., p. 119. 
movement aiming to establish the "international public order" in which "states could no longer view themselves as unrestricted total sovereigns". He prophesised the evolution "from an obligation discerned by the community to a more impartial view, from a simple relationship between self and 'another' to a complex relationship between self and 'others'". The essence of "self" and "others" interrelations has been shaped by ius cogens norms or by "universal law"?

\section{Background}

The forty-year anniversary of the adoption on 22.5.1969 of the Vienna Convention on the Law of Treaties not only provides an opportunity for a legal-dogmatic analysis of the Convention and its implementation, but also encourages a broader reflection on some problems common for the Convention, the law of treaties and international law as a whole. Even if answers will not be forthcoming on every occasion, the mere fact of asking questions provides added value to the anniversary debate. The ius cogens norms constitute the object of this paper's current reflection. The significance of the Convention's Article 53 in international law alone, beyond the Convention and the law of treaties, justifies the choice.

It is possible to state at the outset that the subsistence of ius cogens norms and their cataloguing alone constitutes, or at least determines, the international community and lays the foundations for international relations. Since the international community lacks a system of common values it is, at best, a community at an early stage of development, currently bereft of common objectives stemming from shared values, or institutions capable of simultaneously defending its values and meeting their individual objectives ${ }^{8}$. Such a community possess the features of

6 Similarly to public order in domestic law.

7 Yearbook of the International Law Commission, 1963, p. $59 \mathrm{ff}$.

8 As Hsiung points out: "From the international governance perspective, states have rights and duties not only vis-à-vis one another, but also vis-à-vis the world community (or international society). ...In our usage, for a number of reasons we prefer the term "community" to "society," although they are mostly synonyms. First, "society" smacks too much of Gesellschaft, characterized by formal, contractual bonds and arrangements. "Community," on the other hand, connotes more an organic grouping, like Gemeinschaft, 
a Gesellschaft, without actually possessing the Gemeinschaft character, which is indispensable for a community ${ }^{9}$. The absence or presence of the binder defines the character of international relations, constituting a passengerpassengers-crew-airplane relationship or, in structural terms: participantscommunity-authorities-institution ${ }^{10}$. Recognition and implementation of a common catalogue of ius cogens norms is an essential condition for the transformation of an international law subject's collectivity into a valuebased community. It also denotes the end of history, meaning a transition from the international community (where fist-fighting is permitted) to a community of values (not only allowing to forget the vale tudo period - no rules fighting, but also times when values may have been infringed by simple referral to a formal rationalization).

The topic of any analysis determines the approach and study outlook. I shall not focus on legal analysis, as the dogmatic analysis of ius cogens and its implementation was, and for many years will remain, secondary. Knowledge of the matter - apart from a comprehensive, up-to-date study - comprises works by outstanding representatives of international law doctrine such as: Schwelb ${ }^{11}$, Sztucki $^{12}$, Verdross $^{13}$ and

in which members are aware of one another and share certain common loyalties and values, while, like in a Gesellschaft, they manifest a feeling of belonging together. Second, community is a more decomposable concept. It may encompass a "global civil society" but it may also be at a lower than global level, such as the regional preferential trade associations. Third, functionally-defined groupings in certain issue areas are referred to as a community, not society. In that sense, community's connotation may include society, but not the other way round. The more elastic concept of community, therefore, fits in more comfortably with our discussion of the international equivalent of "man in society," or state in the collectivity of nation-states (community)", J.C. Hsiung, Anarchy, Hierarchy, and Actio Popularis: An International Governance Perspective, Paper for delivery on the Panel on Hegemony, Hierarchy and International Order The International Studies Association (ISA) Annual Meeting, Montreal, Canada, 19.4.2004, p. 14, available at: http://www.nyu.edu/gsas/dept/politics/faculty/hsiung/hsiung_ahap.pdf.

9 See more F. Tönnies, Community and Society, Cambridge University Press 2001.

10 See also A. Orakhelashili, Peremptory Norms in International Law, Oxford, New York 2006, p. $27 \mathrm{ff}$.

11 E. Schwelb, Some Aspects of International Jus Cogens, 'American Journal of International Law' 1967, Vol. 61, pp. 946-975.

12 J. Sztucki, Jus Cogens and the Vienna Convention on the Law of Treaties, Vienna 1974.

13 A. Verdross, Jus Dispositivum and Jus Cogens in International Law, 'American Journal of International Law' 1966, Vol. 60, pp. 55-63. 
Wolfke ${ }^{14}$. It is significant for considering the knowledge of this matter as complete that the co-authors of the VCLT, CIL reporters were, among others, H. Lauterpacht, G.G. Fitzmaurice (who introduced the notion of ius cogens into the Report) and H. Waldock. At the same time, legaldogmatic studies do not exhaust the complexity of the topic. Important issues, including the reasons behind the introduction of Article 53 to the Convention, questions on the motives of this provision and its objectives, and the fundamental query as to whether the declared objective was (or could have been) fulfilled, have remained unexplored.

\section{Function of the query}

The initial question "codification or development?" may introduce a range of research issues. Starting with the literally read query concerning codification, the Conference's factual findings (normative content of international law), the answer to which is classification of its results. The answer, which is anything but apparent, may be a scientifically correct result of historic legal analysis. Notwithstanding the answer's substantial contribution to legal history and international relations (both in terms of diplomacy history and prognosis), it would not considerably develop mainstream international law research. Irrespective of the answer provided, in each case it was an instance of executing the duties imposed on the UN by the UN Charter Article 13(1): "The General Assembly shall initiate studies and make recommendations for the purpose of: (...) encouraging the progressive development of international law and its codification".

Another implicite issue was the binding effect of all, or only some, of the Convention norms for eleven years, until 27.1.1980, when the Convention came into force after meeting the quantitative criterion stipulated by Article $84(1)$ - i.e. with the filing of the $35^{\text {th }}$ ratification or accession document (in the case of Poland, it lasted even 10 years longer - until accession to the Convection on 27.1.1990). This issue is

14 K. Wolfke, Jus Cogens in International Law (Regulations and Prospects), 'Polish Yearbook of International Law' 1974, Vol. 6, pp. 145-162, and Problem norm bezwzględnie wiążących w prawie międzynarodowym [Question of Peremptory Norms in International Law], Acta Universitatis Wratislaviensis 1972, No. 163, pp. 197-207. 
no longer valid. The question is, rather, when the norm stated in VCLT Article 53 became legally binding. In this case, the research problem constitutes a significant international law issue, with implication amongst fundamental legal issues of international relations. In the quest for an answer, the status of agreements containing norms of varied normative character, in terms of their binding power, is considered (there is general consensus that the provisions of certain agreement codify laws, whereas others create legal norms and thus develop the law). Such sui generis hybrid agreements are the instance of not only legal international bodies but also political bodies (e.g. CSCE Helsinki Final Act). The UN Conventions regulating such international law areas as: diplomatic and consular law, the law of treaties, the law of the sea or the law of non-navigational use of international watercourses constitute significant instances of such agreements. The challenges posed by such hybrid conventions are not limited to discovering whether or not particular norms had been binding before the convention became effective, but also relate to the indication of particular norms, splitting them into codified and created. The parties entering into an agreement do not systematize norms according to that criterion, neither in the agreement itself nor during its preparatory works. The Vienna Convention on the Law of Treaties undoubtedly comprises provisions codifying common law norms, which was additionally confirmed by judgments handed down by the ICJ, ECHR, ECJ and arbitral tribunals. In the Iceland fishing areas cases (Great Britain v. Iceland) or the GabčikovoNagymaros case (Hungary v. Slovakia), the International Court of Justice acknowledged the customary character of certain VCLT legal norms, crucial for settling these disputes. This finding was accompanied by the conviction that the VCLT, having also created the norms, contributed towards the development of international law. The latter issue, however, gave rise to dissent amongst scholars. Although lawyers admitted that the VCLT included norms of different origins ${ }^{15}$, even with the prevalence of those leading to a "gradual development" 16 , no wider consensus could

15 See e.g. Wolfke; K. Wolfke, Rozwój i kodyfikacja prawa międzynarodowego. Wybrane zagadnienia z praktyki ONZ [Development and Codification of International Law. Selected Problems from UN Practice], Wrocław 1972, p. 37.

16 Lauterpacht expressed adverse opinion considering solely pacta sunt servanda as a codification, Yearbook of International Law Commission 1966, II, p. 202. See more I. Sinclair, The Vienna Convention on the Law of Treaties, Manchester 1973, p. $12 \mathrm{ff}$. 
be reached. As regards specific norms, opinions were extremely diverse. The reaching of a compromise, or even athorough examination, was constantly impaired by the granting/obtaining of a customary character by norms applied by international law subjects (seemingly, this was the case of norms regulating the registration of objections or amendment of treaties ${ }^{17}$ ).

A comprehensive answer to this query proves extremely elusive. Whereas the ICJ in particular cases has stated on numerous occasions that a particular VCLT norm applies to relations between the parties (despite the treaty not being effective or binding between the parties to the dispute), the opposite situation (i.e. a declaration that a particular norm lacked binding character) which, forming part of the gradual development of law should become binding together with the VCLT and in respect of the parties to the convention, has never occurred.

Certainly, restrictive legalism permits doubts as to whether the lawmaking technique of combining codification with progressive development is within the ILC's (a UN General Assembly advisory body) scope of competencies. Article 15 of the Commission's statute ${ }^{18}$ states:

In the following articles the expression "progressive development of international law" is used for convenience as meaning the preparation of draft conventions on subjects which have not yet been regulated by international law or in regard to which the law has not yet been sufficiently developed in the practice of States. Similarly, the expression "codification of international law" is used for convenience as meaning the more precise formulation and systematization of rules of international law in fields where there already has been extensive State practice, precedent and doctrine.

Taking the above authorisation literally, one area cannot be codified whilst simultaneously being the subject of "progressive development". Only areas outside the scope of "codification" may be "developed progressively". In practice, such a strict division was dropped and the seemingly mutually exclusive options of codification or progressive development

17 See more P. Reuter, Introduction to the Law of Treaties, London, New York 1995, p. $80 \mathrm{ff}$.

18 UN General Assembly Resolution 174 (II) of 21.11.1947. 
were combined, with codification and progressive development forming a symbiotic whole during legislative works.

No international ruling of an international court or an international dispute settlement organ has ever held that the VCLT's catalogue of legal norms contains norms of legal character other than those binding as a reflection of customary international law. Thus, the VCLT has not been considered as developing international law. Courts and international judicial bodies implied as much indirectly when a single norm needed to be considered as a customary one, i.e. as regards the VCLT's extrapolation of an "on the whole" conclusion to a specific instance was not possible (providing proof for the VCLT's codifying character would have not been required for a single norm). Judicial bodies have not only offered no general opinion on this issue, but they have also not stratified the Convention: separating the codification of customary norms from those developing the law.

Far more important is the question of the content of the ius cogens norms catalogue and the closely-related assessment of legislative technique. The issue of the content of the ius cogens norms catalogue has been discussed many times. Both the Commission and the Vienna Conference deliberated this issue. However, except for individual opinions of certain state representatives indicating the instances of slavery, piracy, genocide, illegal use of weapons or international law crimes, no assembly even decided to exemplify ius cogens norms ${ }^{19}$. The International Law Commission evidently resigned from cataloguing peremptory norms ${ }^{20}$.

19 As minimum minimorum the UN Charter commentary on the use of force has been referred to.

20 "The emergence of rules having the character of jus cogens is comparatively recent, while international law is in process of rapid development. The Commission considered the right course to be to provide in general terms that a treaty is void if it conflicts with a rule of jus cogens and to leave the full content of this rule to be worked out in State practice and in the jurisprudence of international tribunals. Some members of the Commission felt that there might be advantage in specifying, by way of illustration, some of the most obvious and best settled rules of jus cogens in order to indicate by these examples the general nature and scope of the rule contained in the article. Examples suggested included (a) a treaty contemplating an unlawful use of force contrary to the principles of the Charter, (b) a treaty contemplating the performance of any other act criminal under international law, and (c) a treaty contemplating or conniving at the commission of acts, such as trade in slaves, piracy or genocide, in the suppression of 
Some instances of ius cogens norms have been included into the draft VCLT commentary. As such, among others, were listed: the extermination of national or ethnic groups, infringements of territorial or political independence, slaves trafficking and piracy as well as rules covered by UN Charter Articles 1 and $2^{21}$. The discussion leading to the adoption of VCLT Article 53, as well as scholarly debate, are driven by the conviction that, at the current stage of international law development, only the UN General Assembly or the International Court of Justice are capable of cataloguing ius cogens norms ${ }^{22}$. Still, reasonable doubts may arise. As regards the UN General Assembly such doubts are, on the one hand, of a legal character (i.e. the non-binding character of such GA resolutions ${ }^{23}$ ) and, on the other hand, of a political character (i.e. the lack of GA competence to provide a law-making forum for the international community to speak with a single voice $)^{24}$. As for the ICJ, the court's competence to do so is questionable, since it surpasses judiciary powers. The existence of such a loophole in the project led the Austrian representative to motion that the regulation should be resigned from.

which every State is called upon to co-operate. Other members expressed the view that, if examples were given, it would be undesirable to appear to limit the scope of the article to cases involving acts which constitute crimes under international law; treaties violating human rights, the equality of States or the principle of self-determination were mentioned as other possible examples. The Commission decided against including any examples of rules of jus cogens in the article for two reasons. First, the mention of some cases of treaties void for conflict with a rule of jus cogens might, even with the most careful drafting, lead to misunderstanding as to the position concerning other cases not mentioned in the article. Secondly, if the Commission were to attempt to draw up, even on a selective basis, a list of the rules of international law which are to be regarded as having the character of jus cogens, it might find itself engaged in a prolonged study of matters which fall outside the scope of the present articles.", Yearbook of the International Law Commission, 1966, Vol. II, p. 248.

${ }^{21}$ A /CONF.39/C.1/SR.55.

${ }^{22}$ See H. Ruiz-Fabri, La contribution de l'OMC à la gestion de l'espace juridique mondial, [in:] C. Kessedjian, E. Loquin (ed.), 'La mondialisation du droit', Paris 2000, p. 347 ff.

${ }^{23}$ See more: The Elaboration of General Multilateral Conventions And of Non-contractual Instruments Having a Normative Function or Objective, Institut de Droit International. Session of Cairo - 1987; and mainly K. Skubiszewski report and IDI.

${ }^{24}$ According to Sloan "only a thin line, or perhaps a porous fence, between codification and development "; B. Sloan, General Assembly Resolutions Revisited (Forty Years After), 'British Yearbook of International Law' 1987, Vol. 58, p. 69. 


\section{Foundations}

The category of ius cogens norms, and indeed the notion itself, was introduced to international law by VCLT Article 53 ("Treaties conflicting with a peremptory norm of general international law"):

A treaty is void if, at the time of its conclusion, it conflicts with a peremptory norm of general international law. For the purposes of the present Convention, a peremptory norm of general international law is a norm accepted and recognized by the international community of States as a whole as a norm from which no derogation is permitted and which can be modified only by a subsequent norm of general international law having the same character.

Ius cogens norm, according to the VCLT, constitute a peremptory norm of international law, with no derogations allowed. An interpretation of the Treaty definition leads to the following conclusion:

- not every norm of international law is of peremptory character;

- the ius cogens character is conferred solely by the entire international community of states ${ }^{25}$. Accordingly, the U.S. has proposed the answer to a profoundly difficult issue: who and how shall define the catalogue of ius cogens norms? The catalogue must be: recognized in common by the national and regional legal systems of the world. The proposal highlighting the inability of reducing law-making "to the level of the man in the street" simultaneously allowed opposition to the process of ius cogens making - with a single state veto ${ }^{26}$;

- the norms are inter aliae binding;

- classification of given provisions as ius cogens norms is final, since such norms may be altered solely by a subsequent of ius cogens norm;

25 Changes of international relations since the Conference make anachronistic non belonging to the category of subjects capable of bestowing legal norms with a ius cogens character of international economic integration organisations (EU/EC - organisation actor).

26 H. Kelsen, op. cit., p. 7. 
- conferring ius cogens character transforms a particular norm into an international law principle.

The dictionary defines a peremptory norm as follows: "1. Final; absolute; conclusive; incontrovertible «the king's peremptory order», positive. 2. Not requiring any show cause; arbitrary "peremptory challenges»" 27.

Such definitions explain the notion sufficiently. Although the very notion has been used innovatively, the category was present within both domestic law systems and, accepted or not, in legal disputes concerning international law.

The VCLT Article 53 categorises international law norms into ius cogens norm: "mandatory and imperative in all circumstances" and ius dispositivum norms, which "merely furnish a rule for application in the absence of any other agreed régime, or, more correctly those the variation or modification of which under an agreed régime is permissible, provided the position and rights of third States are not affected"28.

This, however, does not imply any straightforwardness of the application of the ius cogens category ${ }^{29}$. The doctrine applies the term "principle" not only to binding norms, considered as fundamental, but also to non-binding (non-legal norms), nonetheless, attributed with the character of a "legal principle". Even such a list of the term "legal use" is not exhaustive. In international law the situation is not so complex, since the "principle" notion has the connotation of a directive. Conduct directives create principles, considered as being law making directives and particularly important norms prescribing particular conduct or abstention from such conduct to international law subjects. Application of the term

27 Black's Law Dictionary, 1999, p. 1157. The entry has been slightly modified as compared to the one of the VI edition: "Imperative; final; decisive; absolute; conclusive; positive; not admitting of question, delay, reconsideration or of any alternative. Selfdetermined; arbitrary; not requiring any cause to be shown.", Black's Law Dictionary, 1990, p. 1136.

28 G. G. Fitzmaurice, Special Rapporteur, Third Report on the Law of Treaties, Yearbook of the International Law Commission 1958, Vol. II (A/CN.4/115 and Corr.1.) p. 40, available at: http://untreaty.un.org/ilc/documentation/english/a_cn4_115_corr1.pdf.

29 More on this see J. Menkes, Zasady prawa międzynarodowego [Principles of International Law], 'Państwo i Prawo' 1988, Vol. 10, pp. 75-83 and the bibliographic notes therein. 
legal principle is easier in international law, since it is an element of positive law norms.

Despite the existence of numerous uncertainties of different types, including linguistic uncertainties ${ }^{30}$, ius cogens norms took their place in international law. Practice and doctrine accepted the potential of ius cogens to repel contradicting obligations, thus limiting the legal power of the rule pacta servanda sunt and the freedom of agreements ${ }^{31}$.

The foundations of Article 53 were laid by the oft-quoted opinion of McNair that:

It is difficult to imagine any society, whether of individuals or of States, whose law sets no limit whatever to freedom of contract. In every civilized community there are some rules of law and some principles of morality which individuals are not permitted by law to ignore or to modify by their agreements ${ }^{32}$.

States' acknowledgment of the ius cogens concept derived from such logic. De Castro, representing Spain at the Conference, stated: “...to all moral law, that it was essential to include a provision stating the existence of norms which all States, large, medium and small, must fully respect"33. Exploring the roots of peremptory norms ${ }^{34}$, reference should be made to Stoic having derived this legal concept from the "common order" 35 ". The category "jus naturale necessarium" was referred to by international law classic scholars such as Grotius ${ }^{36}$ and Vattel ${ }^{37}$. Even Bodin, considered to

30 Division into ius cogens and ius dispositivum norms derives from the civil law Roman tradition but not existing in international law; see Report of the International Law Commission 1966, A(6309) Rev. 1, p. 73 and the commentary.

31 See: G. Schwarzenberger, International Jus Cogens, 'Texas Law Review' 1965, No. III, p. $478 \mathrm{i}$ Ch. Z. Rozakis, The Concept of Jus Cogens in the Law of Treaties, Amsterdam-New York-Oxford 1976, p. 15 ff.

32 A. D. McNair, The Law of Treaties, Oxford 1961, pp. 213-214.

33 A/CONF.39/C.1/SR.55.

34 See more R. Nieto-Navia, International peremptory norms (jus cogens) and international humanitarian law, available at: www.iccnow.org/documents/WritingColombiaEng.pdf, p. 3 ff.

35 More: W. Friedmann, The Changing Structure of International Law, Cambridge 1967, p. 102.

36 H. Grotius, Trzy ksiegi o prawie wojny i pokoju [On the Law of War and Peace: Three Books], Warszawa 1957, 1, Ch. 1, X, 5.

37 E. de Vattel, Prawo narodów [Law of Nations], Warszawa 1959, para 9. 
be the founding father of the absolute sovereignty concept, considered „laws of God and nature” the source of limiting sovereignty - state will ${ }^{38}$.

Contrary to the above was an idea which rejected international law norms as having any peremptory character, represented by Guggenheim's opinion:

Les règles de droit international n'ont pas un caractère imperatif. Le droit international admet en conséquence qu'un traité peut avoir n'importe quel ontenu...L'appréciation de la moralité d'un traité conduit aisément à la reintroduction du droit naturel dans le droit des traités ${ }^{39}$.

Still, the ius cogens concept underlying VCT Article 53 was confirmed in international practice predating the VCLT. Despite the relative scarcity of such practice, prominent precedents confirmed the above practice. Krup and others ruling anticipated the VCLT Article 53 norm, declaring that the nullification of an agreement stemmed from its contradicting moral norms:

Under such circumstances we have no hesitancy in reaching the conclusion that if Laval or the Vichy Ambassador to Berlin made any agreement such as that claimed with respect to the use of French prisoners of war in German armament production, it was manifestly contra bonus mores and hence void (emphasis - J.M.) ${ }^{40}$.

The paucity of references contradicting ius cogens norms as a basis for treaty nullification arguably resulted from considering this category of determinants in States' decision-making process ${ }^{41}$. British consideration of the prohibition on slave-trafficking as a pre-condition for state recognition evidences the practical application of ius cogens norms. Lord Canning,

38 J. Bodin, Sześć ksiąg o rzeczypospolitej [Six books of the Commonwealth], Warszawa 1958, L. I, c. VIII.

39 P. Guggenheim, Traité de Droit International Public, Genève, 1953, Vol. I, pp. 57-58.

40 US v. Krupp and others, The I.G. Farben and Krupp Trials, Law Reports of Trials of War Criminals, Selected and prepared by The United Nations War Crimes Commission, Vol. X, p. 152, available at: http://www.loc.gov/rr/frd/Military_Law/pdf/Law-Reports_ Vol-10.pdf.

41 According to Lachs, e.g. The Munich Treaty was void „ab initio” as its was contrary to the law; M. Lachs, Umowy wielostronne [Multilateral Treaties], Warszawa 1958, p. 182. 
the Foreign Affairs Minister ${ }^{42}$, explicitly stated the condition. Oppenheim considered the prohibition on piracy as a customary norm of peremptory character ${ }^{43}$.

States also referred to outer norms, superior to international law, in their treaty practice. The preamble to the Convention on the Laws and Customs of War represents a perfect example of this:

Until a more complete code of the laws of war has been issued, the High Contracting Parties deem it expedient to declare that, in cases not included in the Regulations adopted by them, the inhabitants and the belligerents remain under the protection and the rule of the principles of the law of nations, as they result from the usages established among civilized peoples, from the laws of humanity, and the dictates of the public conscience. $(\text { emphasis - JM })^{44}$

The Covenant of the League of Nations and the UN Charter also indicate the normative hierarchal structuring of international law, manifestly bestowing treaty norms with a peremptory-imperative status. Article 20 of the Covenant provides as follows:

The Members of the League severally agree that this Covenant is accepted as abrogating all obligations or understandings inter se which are inconsistent with the terms thereof, and solemnly undertake that they will not hereafter enter into any engagements inconsistent with the terms thereof. In case any Member of the League shall, before becoming a Member of the League, have undertaken any obligations inconsistent with the terms of this Covenant, it shall be the duty of such Member to take immediate steps to procure its release from such obligations.

The formal counterpart of Article 20 of the Covenant is Article 103 of the UN Charter which states:

42 The speech of the Right Hon. George Canning. More: V. Bulmer-Thomas, Britain and Latin America: a changing relationship, New York 1989, p. 4; also S. Talmon, Recognition of Governments in International Law: with particular reference to Governments in Exile, Oxford 1998, p. $49 \mathrm{ff}$.

43 L. Oppenheim, International Law: A Treatise, H. Lauterpacht (ed.), London 1955, p. 897.

44 IV Hague Convention of 1907. 
In the event of a conflict between the obligations of the Members of the United Nations under the present Charter and their obligations under any other international agreement ${ }^{45}$, their obligations under the present Charter shall prevail.

International legal scholarship has provided a broad dogmatic analysis of both articles, as well as comparative studies of Article 20 of the Covenant and Article 103 of the UN Charter ${ }^{46}$. As regards the Charter, the legal formulation of the norm gave rise to doubts concerning the relationship between this norm and the peremptory character of the UN Charter and legal relations between parties where at least one party is not a UN Member State ${ }^{47}$. Upon the adoption of the UN Charter, its principles were of imperative character solely as regards UN Member States' relations inter se, analogous to the League of Nations Covenant. When analysing Article 103 of the UN Charter from the perspective of the VCLT Article 53, one shall notice that the prevalence of the Charter's obligations is the only legal consequence of Article 103, as opposed to a loss of binding power by contradicting norms.

Thus, referring to ius cogens norms, the answer to the codification or development conundrum is not as explicit as may prima facie have been expected.

The proposal to introduce ius cogens norms to the Convention stemmed from the natural law concept. However, in this instance, it was merely a formal dispute between the supporters of natural law and those of the legal positivism approach. Followers of Kelsen's (positivistic) approach did not reject the strive for moral values achievement in international relations as such but, rather, required them to be distinguished from

45 The Charter use of the broad term "international agreement" encompasses differences of both notions "international agreement" and "treaty".

46 Interesting conclusions regarding lawmaking quality were reached in particular on discrepancies of official language versions. More H. Kelsen, The Law of the United Nations. A Critical Analysis of its Fundamental Problems with Supplement, New York 1951, p. $111 \mathrm{ff}$.

47 See L. Ehrlich, Karta Narodów Zjednoczonych wraz ze Statutem Międzynarodowego Trybunatu Sprawiedliwości. Uwagi wstępne - teksty - komentarze [United Nations Charter and Statute of the International Court of Justice. Preliminary Remarks - texts - commentaries], Kraków 1946, p. 91. 
law itself ${ }^{48}$. Legislation meets this demand, conferring legal character to a moral norm.

Surprisingly enough, the Soviet Union (and other Eastern-bloc countries) opted to include ius cogens norms into the VCLT ${ }^{49}$. Such astonishment does not arise from the actual relationship between the so-called socialist doctrine of law and natural law, since the socialist doctrine had a (vulgarised) natural law character ${ }^{50}$. Wyszyński influenced the concepts of international law and considered the latter as solely expressing the will of the ruling classes of individual states, secured by obligation $^{51}$. The question as to "What the law should be like, or in what way it is to be created?" was examined instead of looking at "what is the law and what it is like?" Socialist legal studies had never met any criteria of positivist studies in the pure law theory regime ${ }^{52}$.

Soviet understanding of ius cogens norms was expressed in the standing of the Soviet Union and other Eastern-bloc representatives. Tunkin placed a collective rule of proletarian internationalism, comprising numerous detailed rules, expressed in Orwell's meta-language essence of the "Brezhnev Doctrine" atop of the ius cogens norms catalogue. In Tunkin's opinion, this rule of initially customary law character has been confirmed "in contractual way" 53 .

48 H. Kelsen, Czysta teoria praw (Metoda i pojęcia zasadnicze) [The Pure Theory of Law], Warszawa 1934, p. $12 \mathrm{ff}$.

49 Socialist law doctrine, to protect itself and the sovereignty, rejected supremacy of international over domestic law, see A.J. Wyszyński, Zagadnienia prawa i polityki międzynarodowej [Questions of international politics and law], Warszawa 1951, pp. 656-7, 667.

50 Law was defined as "a result of objectively conducted activity of a man, serving defined political forces as a mean of targeted influencing social relations" and, pursuant to historical materialism doctrine, was to "die out, (like states)" following a communist society progress. Mała encyklopedia prawa [Small Encyclopedia of Law], Warszawa 1959, p. 515.

51 Ibidem the entry: "international public law" p. 334 originally: "International public law is a set of rules regulating relations of states in the process of their competing and cooperating, expressing the will of those states governing classes and safeguarded with those states individual and collective pressure" A.J. Wyszyński, op. cit., p. 666. This definition expresses official state and law doctrine of the USSR, presented in international law handbooks of all bloc states; see W.N. Durdieniewski, S.B. Kryłow (eds), Podręcznik prawa międzynarodowego [International Law Handbook], Warszawa 1950, p. 10.

52 H. Kelsen, op. cit., p. 7.

53 An agreement confirming the existence and content of "legal and international relations of socialist system states” was, among others Wspólne oświadczenie o wynikach 
Undoubtedly, within the socialist conception of law, there was no place for law nor for moral rules, surpassing the common, supranational will of the ruling classes. Nevertheless, for reasons known only to itself, the Soviet Union pursued the concept of ius cogens and, even more surprisingly, did not indicate that the incorporation into the VCLT, being international law, of ius cogens norms by force of Article 53 constitutes an example of its "development". Oddly enough, the Soviet Union had never been among the custodians of customary "bourgeoisie law". Its viewpoint rather seemed to express a persistent failure to accept the development of international laws ${ }^{54}$. The Soviet Union's readiness to accept a particular norm, whilst still not accepting international law development, must thus have been a law codification, since it could not have constituted legal development.

Nahlik, deploying specific reasoning and logic, argued in favour of codification:

Popular was the opinion that "traditional" international law does not know norms hierarchy. States "will autonomy" resulting from the sovereignty principle allegedly leads to the situation when the states for sake of their mutual relations may repel any norm of genera international law, except perhaps for the Pacta sunt servanda principle, considered indispensible for any international obligations. Over exaggerated opinion ${ }^{55}$. (...) Although ius cogens norms in international law were presented by some, in good faith, as an instance of progressive development, still some stressed codification, thus declaratory character of the said article $e^{56}$.

Paradoxically the success of conferring treaty status to ius cogens norms lacks any discernible authorship, which contrasts starkly with the

rozmów pomiędzy partyjno-rządowymi delegacjami Zwiq̨zku Radzieckiego i Wegierskiej Republiki Ludowej z 9 kwietnia 1958 roku [Common Declaration on the results of talks between party and government delegations of USSR and Hungarian Peoples' Republic], i.e. after the intervention stopping the Hungarian liberation uprising, G.I. Tunkin, Zagadnienia teorii prawa międzynarodowego [Questions of International Law Theory], Warszawa 1964, p. $390 \mathrm{ff}$.

${ }^{54}$ See: A.J. Wyszyński, op. cit., p. 666.

${ }_{55}$ S.E. Nahlik, Kodeks prawa traktatów [Code of the Law of the Treaties], Warszawa 1976, p. 308.

${ }^{56}$ Ibidem, p. 316. 
conclusion that a failure is usually to be considered as an orphan. The Soviet Union and its allies succeeded at the Vienna Conference. The VCLT meets the majority of their objectives and the compromises accepted were minor in terms of their declared expectations and interests. Hence, it is difficult to understand the consequent lack of ratification of the convention by the Eastern Block countries. For many years, such failure was justified by a lack of universalism (for instance, the exclusion of East Germany) and dispute-settlement procedures ${ }^{57}$. However, accession to the UN by post-Soviet countries removed the obstacle. So, the persistent failure to ratify the Convention proves the pretext, as opposed to the meritorious, character of the objection ${ }^{58}$. Accordingly, there may be two reasons behind the Eastern Bloc's rejection of the Convention. The reasons for this objection altered - one substituted the other (no alternatives were presented though), or the real reason was never actually revealed ${ }^{59}$. The reason behind at least the Soviet Union's support for the ius cogens idea as phrased in the VCLT Article 53 seems rather evident: it insufficiently prevents the voluntarism of the application of the pacta sunt servanda ${ }^{60}$ principle (and undoubtedly weakens its binding power, permitting reference to ius cogens norms to be overused solely in order to avoid meeting an international obligation).

\section{Challenges of the practice}

A technique frequently used in international legislation for splitting international law norms into primary and secondary was adopted by the

57 Socialist states objection to the VCLT regulation in this issue proved their lack of "good will" in the Convention preparatory works, as the worked out procedures covered ius cogens norms with extended protection.

58 Poland proves power of reluctance towards VCLT. In the 90's Polish lawyers appealed the state authorities to ratify VCT. One of the appeal initiators and its main editor was prof. K. Skubiszewski. After the transformation of 1989 the same group decided to repeat the appeal and directed it to the Foreign Affairs Minister, Krzysztof Skubiszewski. The first semi-official reaction was to multiply obstacles for the ratification.

59 Speculations are necessary as there is no access to Soviet archives (mainly the party ones).

60 See more in G. Schwarzenberger, op. cit., p. 476, also in J. Sandorski, Nieważność umów międzynarodowych, [Invalidity of International Treaties], Poznań 1978, p. 175 ff. 
VCLT and the Vienna Conference, with the VCLT regulating only matters subject to secondary norms ${ }^{61}$. The introduced of the Art 53 norm gives binding power to a norms catalogue of ius cogens character (stating legal obligations), thereby providing tools for the definition and supervision thereof. This law-making technique undoubtedly facilitates the creation of law, at best hampering the application thereof, but mostly simulates the legal regulation of a legal fiction ${ }^{62}$.

The ius cogens norm category is not free from such threats as are normal in international relations. States weaken the ius coges norms category, if not de facto rejecting such norms, in consequence of the relativisation norm. Pakistan's stance on the International Convention on Suppression of Terrorist Bombing perfectly demonstrates this phenomenon $^{63}$ :

The Government of the Islamic Republic of Pakistan declares that nothing in this Convention shall be applicable to struggles, including armed struggle, for the realization of right of self-determination launched against any alien or foreign occupation or domination, in accordance with the rules of international law. This interpretation is consistent with Article 53 of the Vienna Convention on the Law of Treaties 1969 which provides that an agreement or treaty concluded in conflict with an existing jus cogens or preemptory norm of international law is void and, the right of selfdetermination is universally recognized as a jus cogens.

61 That derives from Hart's idea of primary rules ("rule of recognition") and three categories of secondary rules ("rules of adjudication"). The idea allows the comprehension and evaluation of impact among specific spheres of international law of legal order and the norms interdependence under international law system (H.L.A. Hart, The Concept of Law, Oxford 1961, pp. 78, 79). Pursuant to the idea, primary rules specify obligation to act or abstain from action, while the secondary rules provide for a continuous application of the modified, "old" rules, by setting the instrument of their reinterpretation and control or introducing new rules of conduct to the legal system.

${ }^{62}$ Legal norm made by Article 5 ICC Statute grants the Court jurisdiction over four groups of crimes, which it refers to as the "most serious crimes of concern to the international community as a whole": the crime of genocide, crimes against humanity, war crimes, and the crime of aggression. Still the definition of crime of aggression was not adopted until 11.6 .2010 by the Resolution RC/Res.6.

${ }_{63}$ Adopted by the UN General Assembly on 5.12.1997. 
Firm refusal of the norms contained in the anti-terrorist Convention, including ius cogens norms, with a concurrent instrumental reference to the VCLT Article 53 was met with mild or no reaction from the international community. Only Japan reacted, its government issuing the following statement:

With regard to the declaration made by Pakistan upon accession:

(...) The Permanent Mission of Japan] has the honor to make the following declaration on behalf of the Government of Japan.

When depositing its Instrument of Accession, the Government of the Islamic Republic of Pakistan made a declaration which reads as follows:

"The Government of the Islamic Republic of Pakistan declares that nothing in this Convention shall be applicable to struggles, including armed struggle, for the realization of right of self-determination launched against any alien or foreign occupation or domination, in accordance with the rules of international law. This interpretation is consistent with Article53 of the Vienna Convention on the Law of Treaties 1969 which provides that an agreement or treaty concluded in conflict with an existing jus cogens or preemptory norm of international law is void and, the right of selfdetermination is universally recognized as a jus cogens."

In this connection, the Government of Japan draws attention to the provisions of Article 5 of the Convention, according to which each State Party shall adopt such measures as may be necessary, including, where appropriate, domestic legislation, to ensure that criminal acts within the scope of this Convention, in particular where they are intended or calculated to provoke a state of terror in the general public or in a group of persons or particular persons, are under no circumstances justifiable by considerations of a political, philosophical, ideological, racial, ethnic, religious or other similar nature and are punished by penalties consistent with their grave nature.

The Government of Japan considers that the declaration made by the Islamic Republic of Pakistan seeks to exclude struggles, including armed struggle, for the realization of right of self-determination launched against any alien or foreign occupation or domination from the application of the Convention and that such declaration constitutes a reservation which is incompatible with the object and purpose of the Convention. The Government of Japan therefore objects to the aforementioned reservation made by the Islamic Republic of Pakistan. 
The category of ius cogens norms is quoted relatively often by the International Court of Justice, as in the following ICJ judgement in the Barcelona Traction Light \& Power Company case (the ICJ stated as follows: "Such obligations derive, for example, in contemporary international law, from the outlawing of acts of aggression, and of genocide, as also from the principles and rules concerning the basic rights of the human person, including protection from slavery and racial discrimination.") and in the case concerning the US diplomatic and consular staff in Teheran.

The International Criminal Tribunal for the Former Yugoslavia also referred to the category of ius cogens norms. In the Furundžija case, it stated that there is a ius cogens prohibition of torture, likening torture to piracy and the slave-trade within the category of "hostis humani generis, an enemy of all mankind"64.

That, however, does not satisfy those seeking to broaden the ius cogens norms catalogue (i.e. creating new norms of a ius cogens character or conferring such character on norms already in force). This reasoning can be traced in some statements referring to political matters. References to ius cogens norms resemble references to the use of weapons in many armed conflicts e.g. in ideology-driven disputes with international corporations ${ }^{65}$. Still, far more important are controversies tangential to issues de lege ferenda with the law - legal practice. The absence of a closed catalogue of ius cogens norms may result in controversies in international practice, as proven in the case of Michael Domingues, who was convicted and sentenced to death in Nevada, United States, for multiple homicides committed when he was 16 years old ${ }^{66}$. The Inter-American Commission of Human Rights argued that the ius cogens norm of eighteen years constituted the minimum age at which a crime became subject to capital punishment. The U.S., formally having no obligation to respond to a non-binding report, nevertheless issued an official statement which

64 Prosecutor v. Furundžija, International Criminal Tribunal for the Former Yugoslavia, International Law Reports 2002, pp. 211-213.

65 See: J. Russow, MAI would be in conflict with peremptory norms of general international law and thus be null and void under Article 53 of the Convention on the Law of Treaties, available at: http://www.hartford-hwp.com/archives/25/049.html.

66 Michael Domingues, Case 12.285, Merits, Report of the Inter-American Commission on Human Rights, Report No. 62/02 (2002). 
straightforwardly rejected the Commission's finding on the peremptory character of the norm-proscription ${ }^{67}$.

The Michael Domingues case is of much wider importance than merely the result of imposing capital punishment on minors who committed their crimes when they had not yet reached 18 years of age. The United States rejected the possibility to automatically include all human rights within the ius cogens norms catalogue. Yet no catalogue of human rights peremptory norms was ever formally issued. The opinion of reporting judges in the Nicaragua case included in the Third Restatement of the Law of the Foreign Relations Law of the United States proves the importance attached by the USA to this issue and demonstrates how straightforward their stance on the matter is. The standing enjoys broad support amongst international legal scholars including, among others, Higgins ${ }^{68}$. One argument for denying the ius cogens character of human rights is the different content of the universal and regional catalogues of human rights, which cannot be derogated from (e.g. under UN and regional systems of the Council of Europe or OAS $)^{69}$. That requires a different perception of international tribunals' decisions, which was evident and commonly accepted in the Barcelona Traction Light \& Power Company case. At the same time, those norms indicated by the U.S. as falling within the ius

67 The Michael Domingues Case: Argument of the United States, Office of the Legal Adviser, United States Department of State. Digest of United States Practice in International Law 2001, p. 303 and 310-13.

68 "In general terms, the suggestion has been made that human rights treaties have the character of jus cogens. There certainly exist a consensus that certain rights - the right to life, to freedom from slavery and torture - are so fundamental that no derogation may be made. And international human rights treaties undoubtedly contain elements that are binding as principles which are recognized by civilized states, and not only as mutual treaty commitments. Some treaties may focus almost exclusively on such elements - such as the Genocide Convention - while others may cover a wide range of rights, not all of which may have for the present a status which is more than treaty-base. This being said, neither the wording of the various human rights instruments nor the practice thereunder leads to the view that all human rights are jus cogens"; R. Higgins, Derogation under Human Rights Treaties, 'British Yearbook of International Law', 19767, Vol. 48, pp. 281-2.

69 On the internal order of the human rights catalogue see Th. Meron, On a Hierarchy of International Human Rights, 'American Journal of International Law' 1981, No. 1, p. 80. 
cogens catalogue included, besides the prohibition of the use of force (UN Charter regime), genocide, slave traffic and slavery, apartheid but also "other serious violations of human rights" and "possibly attack on diplomatic staff"70.

\section{Non-legal conclusion}

This objective of this analysis was not to verify that VCLT Article 53 impacts on international law (i.e. has Superman prevented evil?). Those who seek a prognosis verification may refer to the various UN Secretaries' reports in the years following the Vienna Conference. However, adopting the linguistic convention followed by d'Amato and his co-authors, I am sorry to say that if a Golden Raspberries award had been presented for the worst legislation, the least successful normative tool for implementing "good (because moral) law", it would have gone, allegedly also univocally, to the ius cogens norms category. The category which sought the normative constitutionalisation of the international community ${ }^{71}$, its rooting in the axiological order, which constitutes an arena abound with extreme political statements, dangerous judicial activism and with no specified or discernible direction of development. An assessment of legislation technique does not mean, in my opinion, that decisive for relations of international community is the quality of law, meeting the objective of legislative correctness or not.

The presence of uncertainties and threats was clearly visible during preparatory works on the VCLT at the ILC and the codification conference. Representatives of France had consistently warned about threats posed by bad legislative technique. M. Hubert viewed them as legally uncertain ("it declared void (...) an entire category of treaties but failed to specify what treaties they were, what were the norms whereby they would be voided, or how those norms would be determined"), lacking in supervision and lacking any responsibility of those responsible

70 Third Restatement..., $\S 102$.

71 See also P.-M. Dupuy, The Constitutional Dimension of the Charter of the United Nations revisited, 'Max Planck Yearbook of United Nations Law', Vol. 1, p. 30-33, available at: http://149.217.72.46/shared/data/pdf/pdfmpunyb/dupuy_1.pdf. 
for interpretation thereof ${ }^{72}$. Those were the reasons for the French opposition to the legal formula of the VCLT norms' categorisation: "his delegation was not prepared to take a leap in the dark, and to accept a provision which, because it failed to establish sufficiently precise criteria, opened the door to doubt and compulsion"73. It is hard to seek comfort in an inability to foresee the future, since the challenges and threats were evident to all willing to see them. Disregard for them was politically dictated.

What may comfort those co-authors of VCLT Article 53's normative regulation, who acted in good faith and for the benefit of the international community, is that international law to a large extent reflects a lawmaking incompetence, as opposed to noble intentions.

In summary, the international community required the development of international law by bestowing the norm in VCLT Article 53 with ius cogens character both legally confirming or establishing international law norms hierarchy, as well as defining the legal consequences of the discrepancies from the ius cogens concept itself (invalid in whole, impossible to validate, duty to remove effects resulting from actions contrary to ius cogens and restoring the ius cogens conforming state). Art. 53 of the VCLT has met this demand. Still, the international community needed equally good legislation, conforming to the rules of law-making, and this demand was not met by Article 53. This may be considered, however, not as proof of the weakness of law created by the international community but, rather, as a legislative challenge, given that the loophole of the treaty ius cogens norms catalogue can be filled. The defect may be remedied.

72 A/CONF.39/11/Add. 1, p. 93s. and p. 94, No. 8.

73 Ibidem, p. 95, No. 18. 